Gut, 1971, 12, 619-624

\title{
Effect of food on serum gastrin evaluated by radioimmunoassay
}

\author{
M. G. KORMAN, C. SOVENY, AND J. HANSKY \\ From Monash University Department of Medicine, Prince Henry's Hospital, St. Kilda Road, Melbourne, \\ Australia
}

SUMMARY The effect of food on serum gastrin in normal man has been evaluated by radioimmunoassay. Protein and amino acids produced up to a five-fold increase in serum gastrin levels, followed in potency by alcohol, fat, and glucose. Distilled water did not stimulate the release of gastrin. An injection of atropine sulphate $(0.6 \mathrm{mg})$ augmented the response to all good stimuli but in itself did not affect serum gastrin levels in the basal state.

In animals the release of gastrin in response to feeding involves both vagal impulses (Uvnäs, 1942) and the activation of a local mechanism in the antrum (Woodward, Lyon, Landor, and Dragstedt, 1954; Baugh, Bravo, Barcena, and Dragstedt, 1956; Elwin and Nilsson, 1963).

Sensitive radioimmunoassay now permits the direct measurement of gastrin levels in serum, and rises in immunoreactive gastrin have been reported following both feeding (Hansky and Cain, 1969; McGuigan and Trudeau, 1970) and insulin hypoglycaemia (Korman, Soveny, and Hansky, 1971).

This study examines the effect of standard meals and individual food constituents on serum immunoreactive gastrin with and without prior atropinization.

\section{Material and Methods}

Normal healthy volunteers were investigated after an overnight fast. These comprised 20 males and three females between the ages of 20 and 30 years. Subjects were investigated in groups of at least four, and informed consent was obtained from each subject. A 19-gauge needle was inserted into a forearm vein and patency ensured by frequent flushing with a solution of heparin, 1,000 units in $20 \mathrm{ml}$ of $0.9 \%$ sodium chloride. This solution has been shown not to affect serum gastrin levels.

Three groups had a meal which was high in either protein, carbohydrate, or fat, and blood was drawn for gastrin estimation at $-90,-60,-30,0,15,30$, $45,60,75,90,105$, and 120 minutes. The test was Received for publication 12 May 1971. repeated in each subject with intramuscular atropine sulphate $0.6 \mathrm{mg} 30$ minutes before the meal.

\section{PROTEIN MEAL}

Ten subjects had a meal comprising steak and eggs, cheese and milk. Contents of the meal were protein $60 \mathrm{~g}$, fat $51 \mathrm{~g}$, and carbohydrate $11 \mathrm{~g}$.

\section{FAT MEAL}

Eight subjects had a meal comprising eggs scrambled in butter, pears and cream. Contents of the meal were protein $27 \cdot 5 \mathrm{~g}$, fat $61 \mathrm{~g}$, and carbohydrate $11 \cdot 2 \mathrm{~g}$.

\section{CARBOHYDRATE MEAL}

Five subjects had a meal comprising cereal, sugar and milk, toast and honey. Contents of the meal were protein $18 \mathrm{~g}$, fat $9.5 \mathrm{~g}$, and carbohydrate $103 \mathrm{~g}$.

A further five groups were investigated after the ingestion of a specific food constituent. These were alcohol, casilan, glycine, cream, and glucose. Blood was drawn at $-60,-30,0,5,10,15,20,30,45,60$, and 90 minutes. The study was repeated with intramuscular atropine sulphate, $0.6 \mathrm{mg}$, given 30 minutes before the food.

\section{ALCOHOL}

Four subjects had a drink of $250 \mathrm{ml}$ of vodka equivalent to $10 \mathrm{~g}$ of alcohol.

\section{CASILAN}

Four subjects had a drink comprising $60 \mathrm{~g}$ casilan in milk. The contents of this are no carbohydrate, $1.4 \mathrm{~g}$ fat, and $52 \mathrm{~g}$ protein. 
GLYCINE

Four subjects had a drink of $250 \mathrm{ml}$ of $0.3 \mathrm{M}$ glycine.

CREAM

Four subjects had a drink of $250 \mathrm{ml}$ of fresh cream. This contains $7 \mathrm{~g}$ protein, $99 \mathrm{~g}$ fat, and $9 \mathrm{~g}$ carbohydrate.

\section{GLUCOSE}

Four subjects had a drink of $80 \mathrm{~g}$ glucose in $250 \mathrm{ml}$ of water.

Two further groups of subjects were studied and blood was drawn for gastrin estimation at $-60,-30$, $0,15,30,45,60,75,90$, and 120 minutes. Four subjects had a drink of $250 \mathrm{ml}$ of distilled water and six subjects were given $0.6 \mathrm{mg}$ of atropine sulphate intramuscularly.

Of the 23 subjects studied, five had tests involving four or more stimuli, three had three stimuli, and the remaining 15 subjects had one or two stimuli.

The gastrin concentration in $0.5 \mathrm{ml}$ serum was estimated in duplicate by radioimmunoassay (Hansky and Cain, 1969). Since the original report modifications have improved both sensitivity and reproducibility and these will be briefly described. Initially the incubation period for labelled gastrin, antiserum, and unknown was 24 hours which gave $40 \%$ binding in the absence of unlabelled gastrin. More recently, a $\mathbf{7 2}$-hour incubation has given $50 \%$ binding in the absence of unlabelled gastrin. Standard curves (Figure 1) were obtained by the assay of from

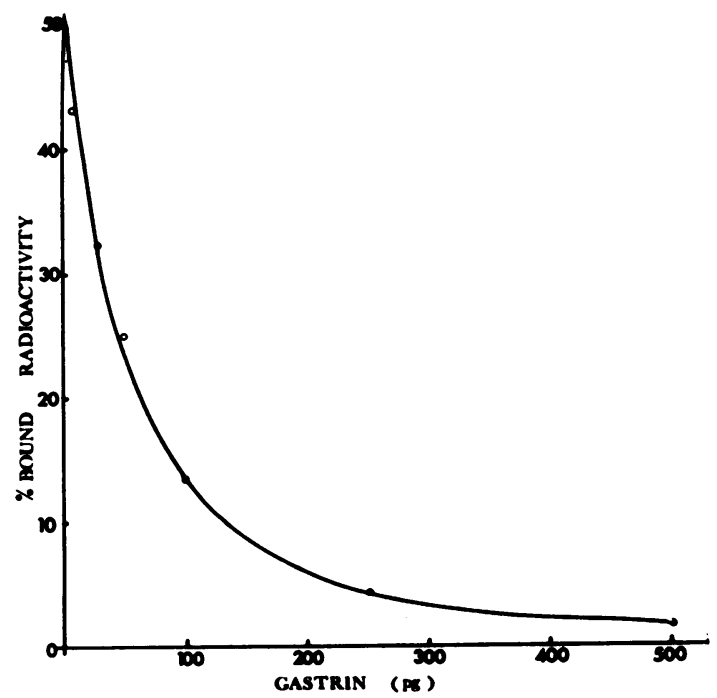

Fig. 1. Calibration curve for radioimmunoassay with antibody (dilution 1/5000) showing percentage antibodybound ${ }^{125}$ I-gastrin plotted against increasing amounts of unlabelled gastrin.
0 to $500 \mathrm{pg}$ human gastrin I (HGI) in $0.5 \mathrm{ml}$ of serum freed of gastrin by prior charcoal absorption. The sensitivity of the assay system is $5 \mathrm{pg}$ per $\mathrm{ml}$. Reproducibility was assessed by freezing aliquots of serum with a gastrin concentration in the middle of the normal range $(\simeq 50 \mathrm{pg} / \mathrm{ml})$. These were assayed serially in lots of five triplicates over a number of weeks so that eight sets of 18 determinations were made. For each group of five triplicates the coefficient of variation was $2.6 \%$ (within-assay variation) and for the eight sets of sera assayed at three-day intervals the coefficient of variation was $7 \cdot 3 \%$ (between-assay variation).

The group means were analysed by Student's $t$ test on an Olivetti table computer using standard formulae.

\section{Results}

PROTEIN MEAL

This (Fig. 2) caused a significant rise in serum gastrin from a mean ( \pm SEM) fasting level of $15 \pm 2 \cdot 3$ $\mathrm{pg} / \mathrm{ml}$ to $78 \pm 16.0 \mathrm{pg} / \mathrm{ml}$ at 45 minutes after ingestion $(P<0.005)$. When repeated with a prior injection of atropine, there was a rise from $22 \pm 3 \cdot 1$ to $88 \pm 10 \cdot 4 \mathrm{pg} / \mathrm{ml}$ at 45 minutes after ingestion $(P<0.005)$. The magnitude of the response was

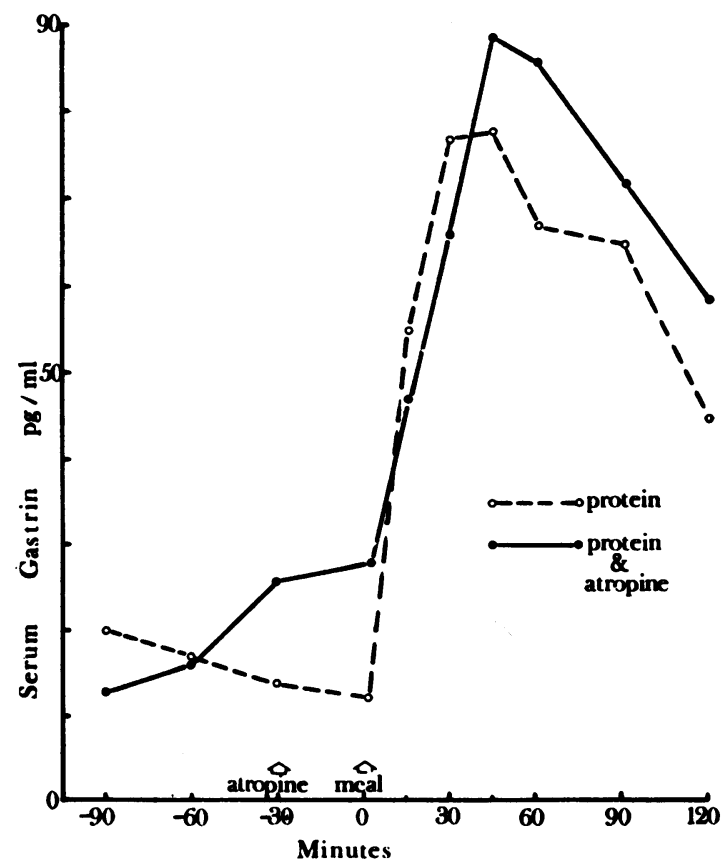

Fig. 2. Serum gastrin response to protein meal with and without prior intramuscular injection of atropine sulphate $0.6 \mathrm{mg}$. 
similar in both studies although the response after atropine was prolonged.

FAT MEAL

This (Fig. 3) caused a significant rise in serum gastrin from a basal level of $24 \pm 8.4 \mathrm{pg} / \mathrm{ml}$ to $52 \pm$ $19.8 \mathrm{pg} / \mathrm{ml}$ at 30 minutes $(\mathrm{P}<0.05)$.

Prior atropinization caused a greater and more significant rise from $25 \pm 6.0 \mathrm{pg} / \mathrm{ml}$ to $78 \pm 11.4$ $\mathrm{pg} / \mathrm{ml}$ at 90 minutes $(\mathrm{P}<0.005)$. The peak response occurred later with prior atropinization and the duration of the response was prolonged.

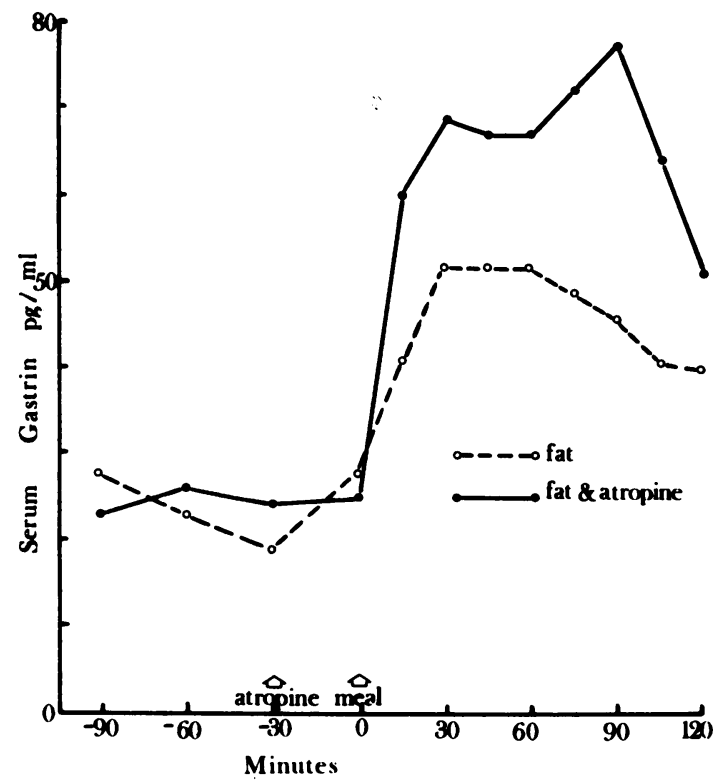

Fig. 3. Serum gastrin response to fat meal with and without prior intramuscular injection of atropine sulphate $0.6 \mathrm{mg}$.

\section{CARBOH Y DRATE MEAL}

This (Fig. 4) caused a significant rise in serum gastrin from $20 \pm 3.4 \mathrm{pg} / \mathrm{ml}$ to $57 \pm 11.5 \mathrm{pg} / \mathrm{ml}$ at 45 minutes $(P<0.005)$. Prior atropinization caused a similar rise from $15 \pm 2.9 \mathrm{pg} / \mathrm{ml}$ to $52 \pm 13.9$ $\mathrm{pg} / \mathrm{ml}$ at 90 minutes $(\mathrm{P}<0.005)$. The peak response was delayed by prior atropinization.

\section{ALCOHOL}

This (Fig. 5) did not cause a significant rise in gastrin $(13 \pm 5 \cdot 6$ to $27 \pm 16 \cdot 3 \mathrm{pg} / \mathrm{ml}$ at 10 minutes, $P=0.15$ ), but prior atropinization produced a significant rise in gastrin from $31 \pm 6.9 \mathrm{pg} / \mathrm{ml}$ to $73 \pm 32.8 \mathrm{pg} / \mathrm{ml}$ at 15 minutes $(\mathrm{P}<0.05)$.

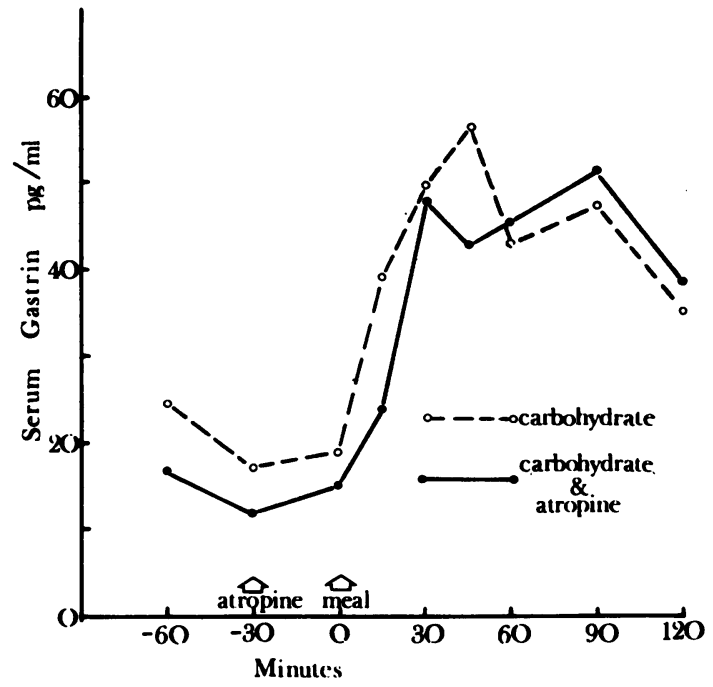

Fig. 4. Serum gastrin response to carbohydrate meal with and without prior intramuscular injection of atropine sulphate $0.6 \mathrm{mg}$.

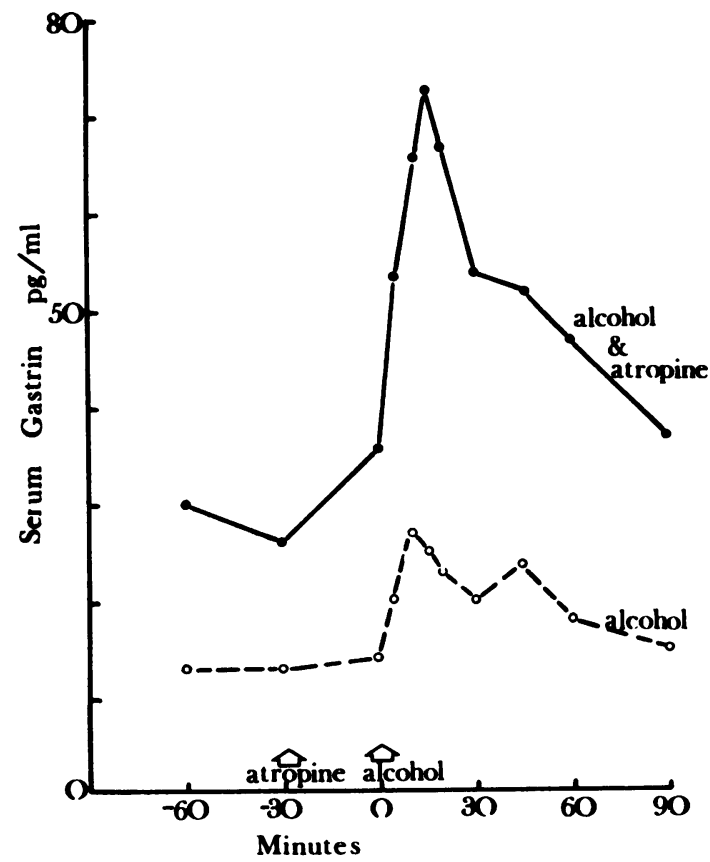

Fig. 5. Serum gastrin response to alcohol with and without prior intramuscular injection of atropine sulphate $0.6 \mathrm{mg}$. 
CASILAN

Casilan (Fig. 6) caused a rise from $31 \pm 9.8 \mathrm{pg} / \mathrm{ml}$ to $78 \pm 36.3 \mathrm{pg} / \mathrm{ml}$ at 15 minutes after ingestion $(P=0.05)$. Prior atropinization caused a greater response from $48 \pm 10.9$ to $135 \pm 79.4 \mathrm{pg} / \mathrm{ml}$ at 45 minutes $(P=0.05)$. This response was of greater magnitude and more prolonged after atropine.

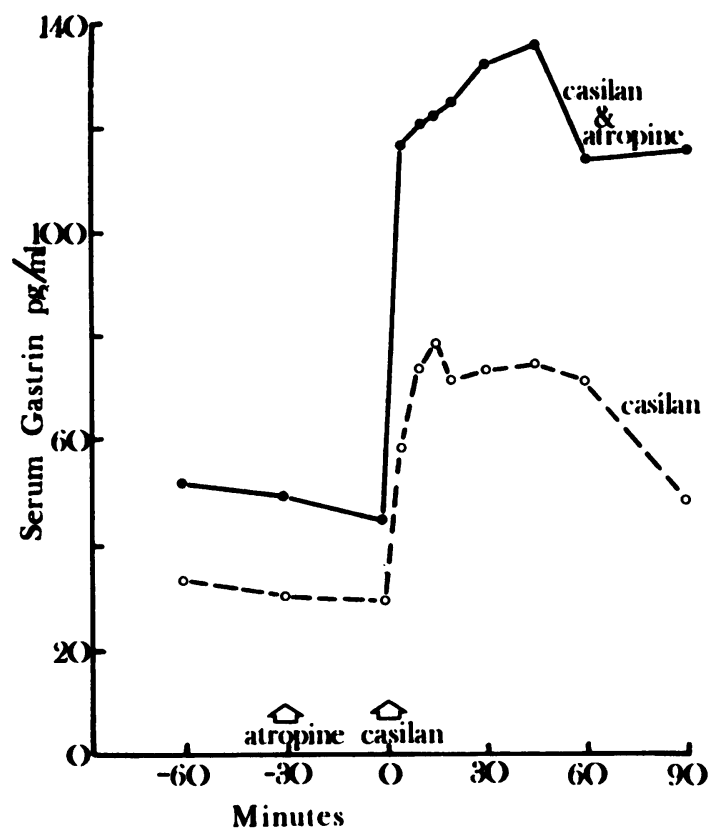

Fig. 6. Serum gastrin response to casilan with and without prior intramuscular injection of atropine sulphate $0.6 \mathrm{mg}$.

\section{GLYCINE}

This (Fig. 7) caused a rise from $12 \pm 3 \cdot 7 \mathrm{pg} / \mathrm{ml}$ to $40 \pm 26.8 \mathrm{pg} / \mathrm{ml}$ at 30 minutes $(P<0.05)$. When repeated with atropine, a greater and significant rise occurred $(17 \pm 4.8$ to $88 \pm 29.3 \mathrm{pg} / \mathrm{ml}$ at 15 minutes, $P<0.005)$. The response after atropine was prolonged.

\section{CREAM}

The ingestion of cream (Fig. 8) did not cause a significant rise in serum gastrin $(32 \pm 4.5$ to $44 \pm$ $13.8 \mathrm{pg} / \mathrm{ml}$ at 15 minutes, $P=0.25$ ). When repeated after prior atropinization, it rose from $23 \pm 15 \cdot 1$ to $57 \pm 13.0 \mathrm{pg} / \mathrm{ml}$ at 30 minutes but again the rise was not significant $(P<0.15)$. However, the response was delayed and of greater magnitude than without atropine.

\section{GLUCOSE}

Glucose (Fig. 9) produced a rise from $1 \pm 0.7$ to

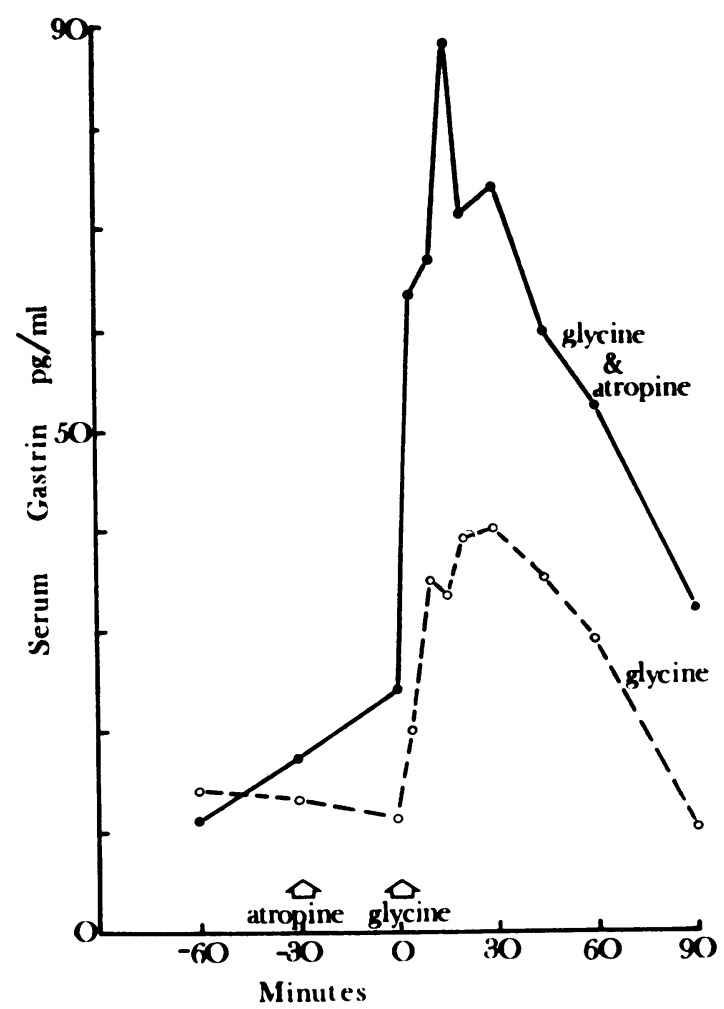

Fig. 7. Serum gastrin response to glycine with and without prior intramuscular injection of atropine sulphate $0.6 \mathrm{mg}$.

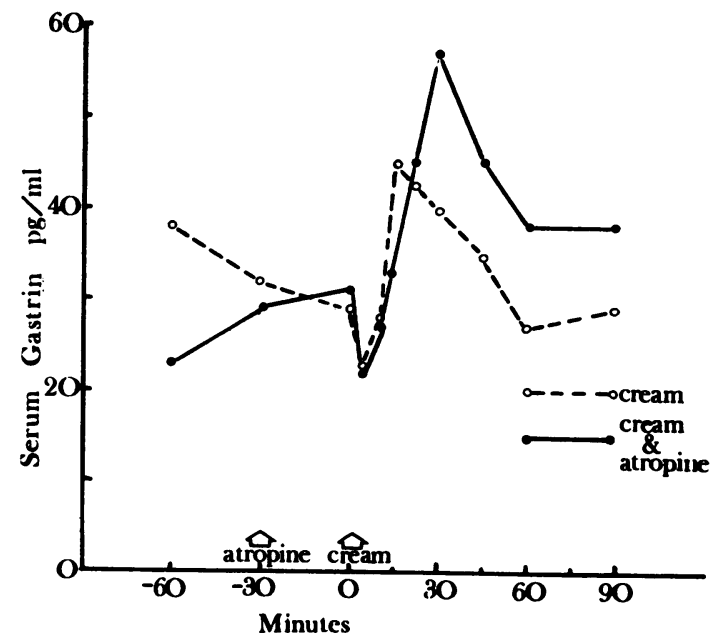

Fig. 8. Serum gastrin response to cream with and without prior intramuscular injection of atropine sulphate $0.6 \mathrm{mg}$. 
$10 \pm 3.8 \mathrm{pg} / \mathrm{ml}$ at 10 minutes $(\mathrm{P}<0.01)$. These figures are close to the limits of sensitivity of the assay and interpretation of the significance of this rise is questionable. Prior atropinization caused a significant rise from $8 \pm 3.3$ to $22 \pm 8.5 \mathrm{pg} / \mathrm{ml}$ at 10 minutes $(P<0.025)$.

Figure 10 shows the response to atropine and distilled water alone. With distilled water, gastrin was unchanged $(19 \pm 2.6$ to $24 \pm 1.8 \mathrm{pg} / \mathrm{ml}$, $\mathbf{P}=0 \cdot 1)$ and similarly with atropine there was no significant alteration in gastrin levels $(28 \pm 5.9$ to $35 \pm 18 \cdot 1 \mathrm{pg} / \mathrm{ml}, \mathrm{P}=0.3$ ).

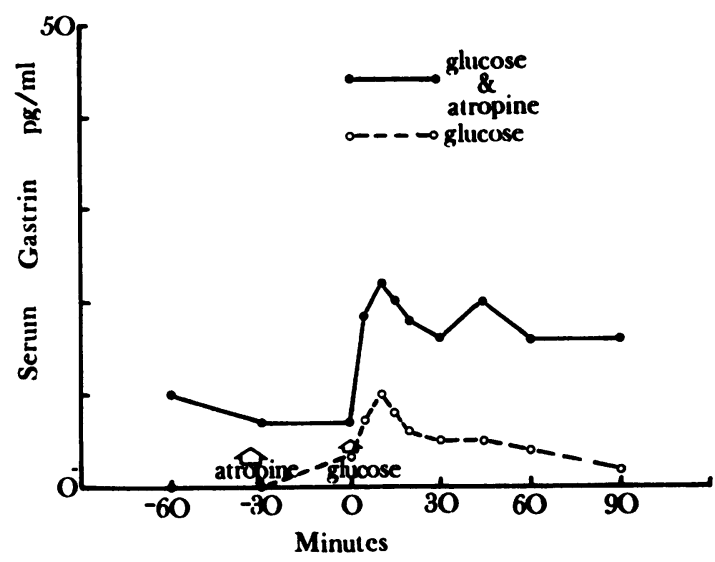

Fig. 9. Serum gastrin response to glucese with and without prior intramuscular injection of atropine sulphate $0.6 \mathrm{mg}$.

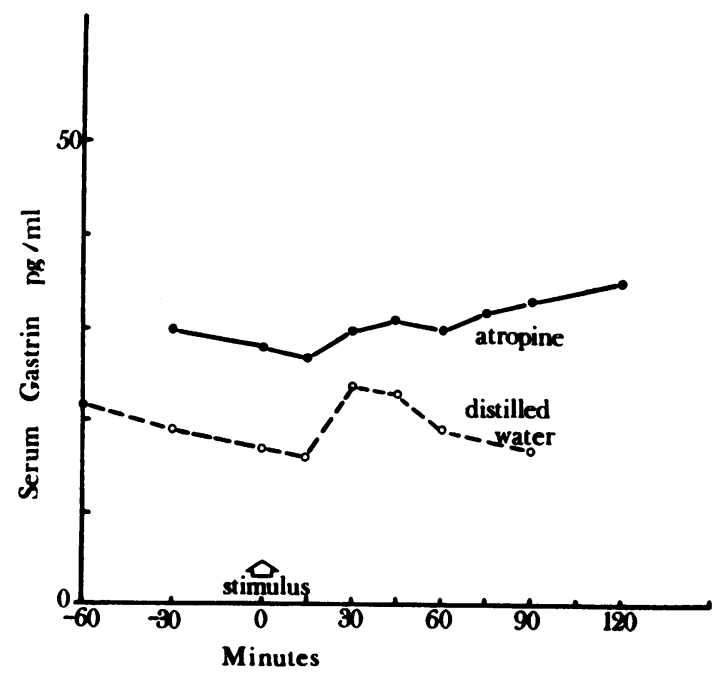

Fig. 10. Serum gastrin response to $250 \mathrm{ml}$ of distilled water and to the intramuscular injection of atropine sulphate $0.6 \mathrm{mg}$.
Discussion

These studies indicate that in normal man the ingestion of various foods elicits a rise in serum gastrin. As judged by the time of occurrence of the peak response this is probably due to local stimulation of gastrin release. That there is a vagal component as well is suggested by the commencement of the response within 10 minutes of ingestion. Although comparisons of stimuli were not always made in the same subjects, a number had their response studied following four or five different stimuli. The responses of these individuals were similar to the mean of each group studied, and hence it was felt that valid conclusions could be drawn in the comparison of different foods.

Cooke and Grossman (1968) compared stimulants of antral release of gastrin in dogs and found that acetylcholine was most powerful followed by glycine, and that ethanol, meat extracts, and sodium bicarbonate were weak stimulants. In the present study it was found that proteins and amino acids were the most potent releasers of gastrin. In terms of increase of gastrin above fasting levels, the figures were $63 \mathrm{pg} / \mathrm{ml}$ for a protein meal, $47 \mathrm{pg} / \mathrm{ml}$ for casilan, and $28 \mathrm{pg} / \mathrm{mll}$ for glycine. Predominantly fat or carbohydrate meals which contained a significant amount of protein raised the serum gastrin level by $28 \mathrm{pg} / \mathrm{ml}$ and $37 \mathrm{pg} / \mathrm{ml}$ respectively. However, pure fat (cream) and glucose produced increments of only 12 and $9 \mathrm{pg} / \mathrm{ml}$ respectively. It is therefore evident that fat and carbohydrates as such are poor stimulants of gastrin release and stimulation by meals containing predominantly these constituents is in the main due to their protein content.

Although there is general agreement about protein and amino acids, Woodward, Robertson, Ruttenberg, and Shapiro (1957) showed that dilute alcohol was a powerful stimulant of the antral gastrin mechanism and this effect was abolished by acidification of the alcohol to a $p H$ of $1 \cdot 2$. In this study alcohol produced a rise in serum gastrin of $14 \mathrm{pg} / \mathrm{ml}$ above basal levels. This was not significant and suggests that in man, unlike the dog, alcohol is a poor stimulant of gastrin release.

Emas and Grossman (1969) found that truncal vagotomy caused an increase in the response of Heidenhain pouches to a feeding meal. They suggested that although the vagal component of gastrin release was eliminated, these procedures produced stasis of food in the stomach and increased the contact time with antral mucosa. The present results after atropine form an analogous situation. Here, casilan, glycine, and a protein meal produced the greatest increase above basal levels $(87 \mathrm{pg} / \mathrm{ml}, 71$ 
$\mathrm{pg} / \mathrm{ml}$, and $66 \mathrm{pg} / \mathrm{ml}$ respectively), followed by alcohol $(42 \mathrm{pg} / \mathrm{ml})$, cream $(34 \mathrm{pg} / \mathrm{ml})$, and glucose $(14 \mathrm{pg} / \mathrm{ml})$. It is of some interest that predominantly liquid meals produced a greater rise in serum gastrin above basal levels in the atropinized state compared to the situation without prior atropine. This suggests that the serum gastrin response to these liquid stimuli is modified by their rapid passage into the intestine and decreased time of contact with antral mucosa, a situation which is partly remedied by atropine. In agreement with Walsh, Yalow, and Berson (1970), atropine alone was shown to have no effect on serum gastrin in normal man in the absence of a chemical stimulant.

It is of interest to compare our results with those of two other series published recently. McGuigan and Trudeau (1970) showed that the peak serum gastrin response to feeding meals, glycine, and sodium bicarbonate occurred from 20 to $\mathbf{4 0}$ minutes after ingestion. These are similar to the findings in the present study where the peak response occurred 30 to 45 minutes after ingestion. However, Byrnes, Young, Chisholm, and Lazarus (1970a), studying both normal subjects and patients with duodenal ulcer, in response to a liquid protein meal found a rapid peak response within 10 minutes which fell to normal levels within $\mathbf{3 0}$ minutes. They also reported levels of up to $26 \mathrm{ng} / \mathrm{ml}$ which are well above those found in the present study or in that by McGuigan and Trudeau (1970).

The time differences of these responses may be explained on the basis that the groups are measuring different components of gastrin (Byrnes, Lazarus, and Young, 1970b). The present assay and that of McGuigan and Trudeau (1970), based on antibodies to human gastrin I, measure gastrin I, gastrin II, and probably 'big' gastrin (Yalow and Berson, 1970), and these may be the forms of 'gastrin' released by local stimulation. Byrnes $e t$ al have an assay based on pentagastrin antibodies which measures all peptides having the $\mathrm{C}$ terminal tetrapeptide sequence of gastrin. Some peptide having this $\mathrm{C}$ terminal group, related to but not gastrin I or gastrin II, may be the form of 'gastrin' predominantly released by vagal stimulation (Hansky, Korman, and Soveny, 1970; Byrnes et al, 1970b). If this hypothesis is true, it would be expected that Byrnes would obtain less stimulation after giving atropine before food whereas we find augmentation of response to food. Further, Byrnes, Lazarus, and Young (1970c) find that atropine causes a fall in basal gastrin levels whereas the present study shows no change. These differences open up a most interesting vista as to the form in which gastrin is secreted in response to different stimuli and inhibitors.
These studies do indicate that there may be some physiological basis for cream, white meat, bread and butter diets in the therapy of duodenal ulceration. Indeed if gastrin has any acid stimulatory capacity then pure protein feedings would be least desirable and pure fat or carbohydrate feedings most desirable. However, any therapeutic applications of the present results would have to be tempered by the assessment of the acid neutralizing properties of substances studied as well as of their ability to release gastrin.

This study was supported by the National Health and Medical Research Council of Australia. The advice and preparation of diets by Mrs Jill Wharton is gratefully acknowledged.

Please address requests for reprints to M. G. Korman, Monash University Department of Medicine, Prince Henry's Hospital, St Kilda Road, Melbourne, Australia.

\section{References}

Baugh, C. M., Bravo, J. L., Barcena, J., and Dragstedt, L. R. (1956). Studies on the site and mechanism of gastrin release. Arch. Surg., 76, 441-446.

Byrnes, D. J., Young, J. D., Chisholm, D. J., and Lazarus, L. (1970a). Serum gastrin in patients with peptic ulceration. Brit. med. J., 2, 626-629.

Byrnes, D. J., Lazarus, L., and Young, J. D. (1970b). The many faces of gastrin. Aust. Ann. Med., 19, 380-381.

Byrnes, D. J.,Lazarus, L., and Young, J. D. (1970c). Effect of vagotomy on serum gasirin in duodenal ulceration. Aust. Ann. Med., 19, 240-243.

Cooke, A. R., and Grossman, M. I. (1968). Comparison of stimulants of antral release of gastrin. Amer. J. Physiol., 215, 314-317.

Elwin, C.-E., and Nilsson, G. (1963). Comparison of the effect on gastric acid secretion of some protein compounds releasing gastrin. Acta physiol. scand., 59, Suppl. 213, 37.

Emås, S., and Grossman, M. I. (1969). Response of Heidenhain pouch to histamine, gastrin and feeding before and after truncal vagotomy in dogs. Scand. J. Gastroent., 4, 497-503.

Hansky, J., and Cain, M. D. (1969). Radioimmunoassay of gastrin in human serum. Lancet, 2, 1388-1390.

Hansky, J., Korman, M. G., and Soveny, C. (1970). Effect of vagotomy on serum gastrin in patients with duodenal ulceration. Aust. Ann. Med., 19, 379-380.

Korman, M. G., Soveny, C., and Hansky, J. (1971). Radioimmunoassay of gastrin: the response of serum gastrin to insulin hypoglycaemia. Scand. J. Gastroent., 6, 71-75.

McGuigan, J. E., and Trudeau, W. L. (1970). Studies with antibodies to gastrin: radioimmunoassay in human serum and physiological studies. Gastroenterology, 58, 139-150.

Uvnäs, B. (1942). The part played by the pyloric region in the cephalic phase of gastric secretion. Acta physiol. scand., Suppl. 13, 1-86.

Walsh, J. H., Yalow, R. S., and Berson, S. A. (1970). Effect of feeding and atropinization on plasma gastrin concentrations (Abstr.). Gastroenterology, 58, 1005.

Woodward, E. R., Lyon, E. S., Landor, J., and Dragstedt, L. R. (1954). The physiology of the gastric antrum and experimental studies on isolated antrum pouches in dogs. Gastroenterology, 27, 766-785.

Woodward, E. R., Robertson, C., Ruttenberg, H. D., and Schapiro, H. (1957). Alcohol as a gastric secretory stimulant. Gastroenterology, 32, 727-737.

Yalow, R. S., and Berson, S. A. (1970). Size and charge distinctions between endogenous human plasma gastrin in peripheral blood and heptadecapeptide gastrins. Gastroenterology, 58, 609-615. 